\title{
Exploring the Implementation of Local Wisdom-Based Character Education among Indonesian Higher Education Students
}

\author{
Nur Alfin Hidayati \\ Student of Doctoral Program at Sebelas Maret University Surakarta, Indonesia \& \\ Lecturer at IKIP PGRI Bojonegoro, Indonesia, nikidanajwasalsabila@gmail.com
}

Herman J. Waluyo

Prof., Sebelas Maret University Surakarta, Indonesia, herman.jwaluyo@yahoo.co.id

Retno Winarni

Prof., Sebelas Maret University Surakarta, Indonesia, winarniuns@yahoo.com

\section{Suyitno}

Prof., Sebelas Maret University Surakarta, Indonesia, yitsuyitno52@gmail.com

Samin is an Indonesian tribe at Mount Kendeng, exactly in the cities of Blora and Bojonegoro. Samin people reject school, fez, polygamy, long trousers, and trade. Although they look like out of date, they have 7 good characters i.e discipline, honesty, responsibility, cooperation, tolerance, social care, and environmental care. This research aimed at investigating the strategies for implementing local wisdombased character education among Indonesian higher education students by focusing on the values sated in Jamuskalimasada book of Samin Community. The data of this phenomenological research were collected by observation, interview, questionnaire, and documentation. The findings demonstrated that teaching character education in the higher education based on local wisdom could be conducted by integrating values and aesthetics in the course, internalizing positive values to students, habituation and training, providing example and model, creating characterized-situation based on local wisdom, and civilizing. Value-based vision of study program or campus can be achieved through educational strategy formulation including value habituation, value role model, value internalization, value integration in learning, and cultural value. Teaching character education was related to both character actualization programmed in the lesson plan and good example provision in the classroom and daily campus activities.

Keywords: strategy, implementation, character education, local wisdom, Jamuskalimasada, Samin

Citation: Hidayati, N. A., Waluyo, H. J., Winarni, R., \& Suyitno. (2020). Exploring the Implementation of Local Wisdom-Based Character Education among Indonesian Higher Education Students. International Journal of Instruction, 13(2), 179-198. https://doi.org/10.29333/iji.2020.13213a 


\section{INTRODUCTION}

Educating moral, character, and ethics has become an interesting thing in Indonesia (Saidek et.al, 2016; Arifin et.al, 2017; Atmajawati \& Hening, 2018; Suyatno et.al, 2019). This interesting issue has been an international issue particularly related to the implementation of character education (Turan \& Ulutas, 2016; Lewis \& Ponzio, 2016; Termiz, 2016; Brata et.al, 2017; Tutkun et.al, 2017; Savucu et.al, 2017; Christen, 2018; Rambe et.al, 2018). Education in Indonesia also concerns with character education as the existing social changes have brought to the changes of human character. Many Indonesian teenagers have problems with their behaviors and negative attitudes. Therefore, Indonesian government instructs and emphasizes to have character education (Government Regulation of the Rupublic of Indonesia No. 87 in 2017).

Lately, there have been a lot of studies on character education using culture and local wisdom as the sources of teaching and learning (Eres, 2015; Saripudin \& Komalasari, 2016b; Anggraini \& Tuti, 2017). Some researchers consider character education from the concepts of constitution, cultural values, personality agencies, and the correlation between culture and human beings. In this context, culture including local wisdom becomes one of sources for implanting character education (Guseynov, 2017).

Many studies on values education have been conducted by many researchers in both Indonesia and other countries. Ulavere and Veisson (2015) emphasize the role of lecturer in character education extracted from regulation as the source. Savucu, et al (2017) find that students who have good values can reduce bullying tendency at school. Chong \& Cheah (2009) conclude that values must be owned by lecturers in Singapore so as tonbe successful in implementing character education curriculum dug from internal culture. In addition, research on value education in Indonesia have been carried out by Arifin, et al. (2017); Komalasari \& Saripudin (2018); Suyatno et.al (2019). Anggraini \& Tuti (2017) reveals the importance of cultural values at schools in terms of school management, learning process, teachers, students, and school practitioners; these values refer to Indonesian local wisdom. Sutiyono (2013) argues the importance of character education from culture such as local wisdom. Unlike the previous research, this research focused on the strategy and implementation in implanting character values to higher education students derived from local wisdom of Jamus Kalimasada book of Samin community in Bojonegoro.

The significance of good character to higher education students is giving them skills and examples needed toovercome challenges and problems in their social lives (Stallions \&Yeats, 2003: 250; Silay, 2013: 111). University students with good characters are expected to employ and improve moral values as well as to actualize moral values in their daily lives (Healea, 2006: 66), to make responsible and good decision (Novianti, 2017), and to be good citizens (Çubukçu, 2012; McElmel, 2002). Moreover, by having good characters, university students will tend to improve their learning achievement (Park, 2004: 53). These situations describe that good characters will contribute not only to the development of socio-emotional aspects but also cognitive aspects.

Good characters are reflected in good behaviors and actualized in daily lives (Skaggs, 
2006: 83). These good characters are encouraged from knowledge on good characters themselves. Therefore, good characters must have three unseparated components namely the aspects of moral knowledge, moral feeling, and moral attitude (Lickona, 1991). Moral knowledge aspect is related to building moral awareness, knowing moral values, considering other people's perspectives, implanting moral thinking, and considering moral in decision making (Thompson, 2010).

The integration of character education in the teaching and learning process is initiated by having a good model of lecturer to exemplify the students (Stallions \& Yeats, 2003). Silay (2013) states that a strategy to implant character education in learning process is by providing good model showed by lecturers within their interaction with students in the classroom. Intervention in character education is carried out through a learning process containing character values which are integrated with the course (Tutkun et. al 2015; Novianti, 2017; Bachr, 2017) and community learning from local wisdom (Yusuf, 2018: 248). Besides, to improve character and moral values, some cultural sources from the local community which are considered good and consistent for teaching can be implemented (Halim \& Wardana, 2018: 127).

In reality, implementing character education extracted from local wisdom finds some obstacles. Lee (2009) identifies at least four major problems in educating character at higher education as follows: (1) some lecturers have professional capacity in moral domain and character education; (2) some parents do not have willingness for taking roles in character education process; (3) students have academic pressure that make them more focus on the academic achievement (cognitive aspect); and (4) challenges in preserving character education continuously. Moreover, Almerico (2014) states that some challenges encountered by teachers in teaching character education are related to teaching materials inside the curriculum and teaching strategy. Character education must reinforce the character of local wisdom. These problems must be solved so that character education can be actualized.

The values of character education being developed in Indonesia are derived from religion, Pancasila, culture, and national education purposes including: (1) religious, (2) honest, (3) tolerant, (4) discipline, (5) hardwork, (6) creative, (7) autonomous, (8) democratic, (9) curious, (10) nationalistic, (11) love of country, (12) respect to achievement, (13) communicative, (14) love of peace, (15) habit of reading, (16) environmental care, (17) social care, and (18) responsible (Puskurbuk, 2011: 3). Character education in higher education is conducted through Three Pillars of Higher Education, organization culture, student's activity, and daily activity (Tim Pendidikan Karakter Ditjen Dikti, 2011). Samin community has already had the above characters which can be used as the source for character education. Teaching character using local wisdom is an absolute thing for any education level (Mungmachon, 2012: 174). This statement is reasonable as character education becomes the main foundation for the youth growth and it can preserve the local wisdom.

Considering its significances, character education must be implemented and integrated in higher education in terms of indoor and outdoor learning. Character education plays vital roles in the teaching and learning process. It is emphasized on the character derived 
from local wisdom of Samin community stated in the Jamuskalimasada book. According to Halim \& Wardana (2017), character education in Indonesia cannot be well implemented. This kind of situation indicates that there must be a review in finding strategies to improve the characters of university students and identify the effects of those strategies. Accordingly, this research aimed at answering the question of How effective the implementation of local wisdom-based character education at higher education students by focusing on the characters in Jamuskalimasada book of Samin community and what kinds of strategies the researcher can use to implement it.

\section{Jamuskalimasada Book of Samin Community}

Jamuskalimasada book contains revelation accepted by Samin indigeneous leader namely Mbah Harjo Kardi. It was written in Javanese letter on the sheets of goat skin during the Dutch colonization in 1800-1942. This book is still original and not being copied on paper. Some major precepts held by Samin community are: 1) religion becomes the first and most principle in life. Therefore, Samin people are not hate each other and do not distinguish various religions because the most important thing is character of life; 2) No disturbing others, no fighting, no jealousy, no taking other's property; 3 ) be patient and no arrogance; 4) every human must really understand his life because life is eternal. According to Samin community, life and soul are in unity so died people actually do not die but they just put off their souls; 5) be careful in talking, honest, and tolerant. To Samin people, trading is not good because it contains dishonesty. They are also forbidden to receive aid financial.

Although, Samin people are still living in the remote area around Mount Kendeng in between East Java and Central Java Provinces-Indonesia, they can peacefully live in this modern era without involving themselves in the recent lifestyle. They keep their principles in terms of culture, social behavior, language, clothes, family system, marriage, environmental behavior, housing, tradition, and ceremony. They can survive in this advanced science and technology reflecting that they have good and positive characters in life.

\section{THEORETICAL REVIEW}

Many experts try to describe the concepts of value and educational value. According to Lickona (2004), value is concrete behaviour or moral implementation. Good character underpinning the moral will be called value if it is actualized in visible behaviour. Yildirim \& Dilmac (2015) argue that values are closely related to emotion, thought, and behaviour of human beings. Senturk \& Aktas (2015) explain that human beings as social creatures accommodate their community by absorping value, attitude, and belief. Cavus (2015) reveals that values do not only influence culture but also the quality of good citizens. The symptoms of values can be seen in daily lives. Print (2000) explains that values hold vital roles in educational and developmental processes of community, particularly in democratic community. Therefore, educating values is very important to be implemented in the family, school, and social community (Nguyen, 2016). Good character values can create transparent situation, honest communication, strong relationship, respect to others, trustworthiness, positive attitude to friends, emotional 
expression and sentiment, and self-esteem growth (Sankar, 2004). Good values of students can decrease intimidation tendency among them (Savucu, et al., 2017). Moreover, the research of Bette (2011) finds that character education can serve as catalisator of national development.

Character education is defined as a planned and systematical approach to have selfesteem, responsibility, honesty, act to be good citizens (Çubukçu, 2012), as conscious efforts to influence students' behavior through repeated adaptation (Komala \& Saripudin, 2014), as a process to implant characters for promoting personal development among youths through moral and good values (Bart et. al, 2018), and as academic achievement that must be developed to teach students about character derived from local wisdom (Anggraini \& Tuti, 2017). The aims of character education are to grow the student's ability in understanding moral values and using this capacity to take "good and the best" action as well as to understand the real purposes of student's life (Ülger et. al., 2014). Besides, character education plays roles in improving the quality of learning at campus directed to achieve character of students and to shape nation's moral (Termiz, 2016). Character education also has positive relationship to academic and affective success as well as positive perception (Amani, 2013; Thompson, 2010).

In Indonesia, value education has been employed in higher education system. There are 18 values that must be integrated by lecturers in the teaching and learning process. These values are developed by integrating values of local wisdom of Samin community living at Jepang Hamlet, Margomulyo Village, Bojonegoro. Samin people have honesty, responsibility, cooperative, respect to others, social care, environmental care, high tolerance which are implemented in their daily lives. Those characters are derived from Jamuskalimasada book containing written curriculum, unwritten (hidden) curriculum, co-curriculum activity, and extracurricular activity (Komalasari, 2012). Values that will be built must be actualized in every subject through learning process, inside and outside the classroom and also realized in the classroom regulation. Sutiyono (2013) explains that design of value education must not be presented in certain courses instead of being the content of every learning activity at school. Thus, every course must contain values of character education.

Krull (2000) argues that character values must be transferred to all learning and educational activities in higher education. Besides, this research emphasized the significance of vision formulation of department and campus based on character value. Basically, vision has more important roles as educational strategy is implemented to get the vision of higer education. The research of Raihani (2008) proved that a successful school begins from vision formulation as it becomes the guidance of all policies, programs, and activities inside.

Implanting values to university students can be achieved through many ways. Pornpimon (2014) finds six strategies to shape values within sustainable process, namely habituation values, cultural values, moral knowledge, feeling and love of goods values, moral action, and exemplary. Mislia \& Darman (2016) convey that strategies commonly used in building character of students are intervention, role model, habituation, facilitation, reinforcement, and involvement of others. 
Bojonegoro has popular local culture or local wisdom which can be used for teaching character education. Samin community living at Jepang Hamlet, Margomulyo Village, Bojonegoro has Jamuskalimasada book for its followers. This can be utilized as a source for teaching character education. Jamuskalimasada book consists of four serats or books namely Serat Punjer Kawitan, Serat Pikukuh Kasajeten, Serat Jati Sawit, and Serat Lampahing Urip. All of those four serats teach about discipline, honesty, responsibility, cooperation, respect to others/tolerance, want to do good things/social care, and environmental care. Samin people preserve and practice these cultural characteristics in their daily lives (Hidayati et.al, 2019). Those precepts can be adapted to develop character education for higher education reflecting Bojonegoro people, Samin community in particular. Lecturers can take roles in implanting character education for their students.

The existence of Samin Community characters and precepts which are out of date in the advanced science and technology era is a phenomenon. The way of life of Samin people has shown that they can survive living with their tribal system up to now. This researcher employed phenomenology design it attempted to get behind the most elementary experiences of everyday life of Samin community to look at their inner structure and how the mind makes them what they are. Although phenomenology may focus on personal experience, one of its primary goals is to understand the real world. In classic usage, the term phenomenology means "the study of appearances". In current usage, introduced by Husserl, it means studying the ways in which things appear to consciousness and, therefore, also the way in which consciousness is structured such that things appear to it in the ways that they do. According to Husserl's phenomenology, consciousness is always "intentional" (Husserl, 1962). Phenomenologists argue that such an understanding must precede research on such human concerns as fear, anxiety, the forms of motivation, and the processes of learning, creating, and deciding. Samin community consists of indigenous people continuing in different forms as a means of maintaining its existence and the life of its subjects. Indigenous studies can be used as a mode of analysis which can offer accounts of the contemporary world of Indigenous peoples that centre our ways of knowing and theorizing.

Lecturers can contribute in using local wisdom to teach character education. According to Lovat \& Clement (2008), there are two duties of lecturers i.e. character education and "the rest". Therefore, lecturers need to seek strategies to teach good characters to students in both formal and non-formal education. The role of lecturers to exemplary for their students is very fundamental in teaching character education (Ulavere \& Veisson, 2015). As a reference of value education, a lecturer needs to create suitable environment to develop student's character. Chong \& Cheah (2009) argue that main values that must be owned by somebody to support the awesome implementation of curriculum at National Institute of Education (NIE), Singapura are: believe that all students can learn, appreciate and give attention to all students, respect to diversity, have commitment and dedication to profession, cooperation, share, and tough group work, learning motivation, strength, and innovation. 


\section{METHOD \\ Research Design}

This research belongs to a phenomenology as it attempted to explore the experience of implementing local wisdom-based character education among Indonesian Higher Education students by focusing on the characters mentioned in the Jamuskalimasada Book owned by Samin Community. Phenomenology was chosen because it developed a complex account of temporal awareness (within the stream of consciousness), spatial awareness (notably in perception), attention (distinguishing focal and marginal or "horizonal" awareness), awareness of one's own experience (self-consciousness, in one sense), self-awareness (awareness-of-oneself), the self in different roles (as thinking, acting, etc.), embodied action (including kinesthetic awareness of one's movement), purpose or intention in action (more or less explicit), awareness of other persons (in empathy, intersubjectivity, collectivity), linguistic activity (involving meaning, communication, understanding others), social interaction (including collective action), and everyday activity in the surrounding life-world (in a particular culture). All those awarenesses were in the frame of local wisdom-based character education derived from Samin Community. Phenomenological research is aimed at exploring experiences and sensory perception (from hearing, seeing, feeling, thinking, acting, etc.) of the researched phenomenon. A researcher applying phenomenology is concerned with the lived experiences of the people (Greene, 1997; Holloway, 1997; Kvale, 1996; Maypole \& Davies, 2001; Robinson \& Reed, 1998) involved, or who were involved, with the issue that is being researched. Phenomenology belongs to a study of structures of consciousness as experienced from the first-person point of view. Thus, intentionality, consciousness, and first-person perspective become the main phenomenological issues.

\section{Participants}

This research was carried out at a private university, IKIP PGRI Bojonegoro, in the academic year of 2018/2019. It is a university graduating teacher candidates of Indonesian language education. The research subjects were selected by purposive sampling technique to reach the research goal. It is non-random sampling by stating certain criteria for the research participants. The subjects of research were one person as the head of Indonesian Language Department, two lecturers teaching the course of Basic Culture Science, and 64 students joining that course. In detail, they were class IA consisting of 10 boys and 22 girls and class IB consisting of 9 boys and 23 girls. All of them were from Indonesian Language and Literature Department who were involved in the course of Basic Culture Science, so they were not compelled to participate in this study. Both lecturers and students have known about Samin Community and their characters in the previous course namely Indonesian Literature.

\section{Data Collection}

The data were collected by interview, observation, documentation, and questionnaire. Interview aimed at getting the data or information related to the campus policy in educating discipline character. Observation was utilized to see strategies and implementation of character education inside and outside the classroom. Questionnaire functioned to measure cognitive/understanding of students on character education. In 
data extraction, the researcher took role as a human instrument. The researcher was assisted by guidance of interview, observation, document analysis. Character belongs to affective domain. According to Andersen (1980), there are two methods for measuring affective domain, namely observation and interview. Observation is based on the assumption that affective characteristics can be noticed from behavior or action, psychological reaction, or both. Documentation technique was used to get the data on campus regulation and lesson plan made by the lecturer. Moral instrument was aimed at exploring moral information obtained through observation on action and self-report by filling questionnaire. Information from observation and questionnaire became vital as it was about personal moral.

To determine the affective domain of students, educator must prepare himself to note down every behavior acted by students based on the indicators of affective domain. For this reason, substantial indicators had been determined, such as indicators of honesty, responsibility, cooperation, respect to others, willingness to do good things, etc.

\section{Data Analysis}

Data analysis was carried out quantitatively and qualitatively. Inductive-interactive model of Miles and Huberman (1994) was employed in this research. This model involved three phases: data reduction, data presentation, conclusion, and verification. Quantitative data were analyzed by calculating average values of lecturer's tendency in giving assessment on character education. There were 18 components of character which have been conducted in the curriculum. Average score pre-and-post curriculum implementation were presented in a table. Data on strategies and obstacles in conducting character education were analyzed by implementing phases of Creswell (2013) as follows: (1) arranging data; (2) reading and writing memo; (3) describing, classifying, and interpreting data in codes and themes; (4) interpreting data; and (5) presenting and visualizing data. The whole data were interpreted to get the understanding on strategies and obstacles of lecturer in teaching character education.

\section{Validation of Data Accuracy}

Data checking through triangulation was carried out to get valid data. It is crosschecking information from various sources or methods (Arikunto, 2010:18). The researcher employed triangulation method through documentation and observation.

\section{FINDINGS}

\section{Strategies to Implement Character Education}

\section{Lesson plan}

Implementation of Character Education at Indonesian Language Education Department, IKIP PGRI Bojonegoro was generally carried out by: 1) curriculum development, 2) academic culture among lecturers, work discipline, and students, 3) habituation activity, 4) talent and passion development and coaching. Its implementation was integrated in the course of Basic Culture Science through CTL (Contextual Teaching and Learning) model with the theme of basic binding for character education integration. Some phases 
that the lecturers took for integrating character education using local wisdom were: 1) preparation phase including preparing the implementation, mapping the Basic Competences, describing Competence Standard and Basic Competence into indicators, determining theme and its network, identifying and analyzing Competence Standard, Basic Competence, indicator, syllabus, and lesson plan; 2) implementation phase including the activities of preliminary, core activity (lecturer integrated character education based on the teaching material or theme), and closing; 3) assessment and assignment in the forms of stimulus and written exercise.

Syllabus development and lesson plan arrangement including lesson plan revision were carried out to integrate character education. Lesson plan was revised through the following phases:

First, revising/adapting the learning objectives in two ways: 1) revising the existing learning objectives into cognitive and psychomotor competences, 2) adding characters mentioned in the learning objectives.

Second, changing the learning approach/method by adjusting it with CTL model. It was aimed to integrate local wisdom of Samin community to teach character education.

Third, revising CTL learning phases (preliminary, core, and closing activities) by relating them to Samin characters so as the students have knowledge and skill being targeted. The principles of CTL approach were very effective in developing student's character within Samin culture context in the classroom.

Fourth, revising the assessment by changing and/or adding assessment technique to measure character education in the context of Samin character achievement. Assessment techniques were selected to achieve competence and character wanted to have by students.

Fifth, preparing the teaching materials which were taken from textbooks and giving additional materials about Samin characters in the material discussion. The existing textbooks have met the feasibility criteria such as content, presentation, language, and graphics. However, their materials have not been suitable for integrating character education using Samin local wisdom yet. If the lecture only followed the activities inside those textbooks, character education would not run well. Therefore, based on the syllabus and lesson plan with character education insights, the teaching materials must be adapted. The most possible adaptation done by the lecturers was adding the learning activities to develop character. The other way was by adapting or changing the learning activities in the textbook being used. Besides, adaptation could also be conducted by revising the learning substantial using the theme of Samin local wisdom.

\section{Learning implementation}

Learning activities from opening, whilst, and closing were selected and conducted so as the students practiced the character values being targeted. Principles of CTL (Contextual Teaching and Learning) were applied to facilitate the internalization process of student's character. Besides, the behavior of lecturers during the teaching process became the model of values implementation for the students. 
During the learning process, lecturers must design learning phases to facilitate the students becoming active from the opening and whilst to the closing activities. Lecturers were demanded to acquire the learning method, model, and strategy so that the learning phases could be practiced well. They could do observation and evaluation (assessment) upon the existing process, particularly the student's character.

\section{Learning evaluation}

Evaluation and assessment hold vital roles in educational process. In the context of character education, assessment must be carried out well. The assessment does not only focus on the cognitive domain but also affective and psychomotor ones. Character assessment more emphasizes the achievement of affective and psychomotor domains than cognitive. Table 1 described the result of character learning at Indonesian Language Department.

Table 1

The Results of Observation on Character Learning to the First Semester Students at Indonesian Language and Letter Department

\begin{tabular}{llll}
\hline \multicolumn{1}{c}{ Character Education } & Grade I-A & Grade I-B & Note \\
\hline Discipline & $37.5 \%$ & $75 \%$ & Begin to develop \\
Honesty & $31.2 \%$ & $78 \%$ & Begin to develop \\
Responsibility & $37.5 \%$ & $90.6 \%$ & Become a habit \\
\hline Cooperation & $68.7 \%$ & $87.5 \%$ & Become a habit \\
Respecting others/tolerance & $62.5 \%$ & $84.5 \%$ & Become a habit \\
Social Care & $75 \%$ & $75 \%$ & Become a habit \\
Environmental Care & $62.5 \%$ & $87.5 \%$ & Become a habit \\
\hline
\end{tabular}

Notes: Not clearly seen yet (1-8)

Begin to emerge (9-16)

Begin to develop (17-24)

Begin to be a habit or culture (25-32)

Table 1 showed that the effectiveness of five dimensions of students' characters. Responsibility, cooperation, respecting others, social care, and environmental care had become the habit. It meant that those five characters belonged to the culture of their lives. Meanwhile, discipline, and honesty were in the category of beginning to develop, not culture yet. This condition indicated that the integration of character education in the classroom learning and guidance of character culture were effective in campus. Thus, discipline and honesty showed relatively good development. Both aspects/characters were not easily increased. Teaching character education which is integrated with the classroom learning and guidance of character culture at campus has not been effective yet to improve discipline and honesty of students.

\section{Implementing Character Education}

Building student's character becoming culture requires some phases in creating characterized situation (full of values) first. This creation is greatly influenced by situation and condition where the learning model is applied and the implementation of values. 
Development of education to actualize character education at Indonesian Language Department can be done through the approaches of habituation, exemplary, and persuasive to all academic actors. Giving reasons and good prospects convincing them about the significance of character education is one step ahead. Making their own proaction, determining their ways, and reading actions emerging in community can contribute to the development of character education at campus. Anticipation step can also be taken by actively creating ideal situation and condition to reach the ideal purpose.

Character education is an educational system developing character values to students so that they own and implement those characters in their lives. Indonesian Language Education Department of IKIP PGRI Bojonegoro has strengths in implementing character education as it is a campus creating teacher candidates. Using characters of Samin community, character education in this institution was easy to be employed. Table 2 presents the result of student's questionnaire on the implanting process of character education at this campus.

Table 2

The Result of Questionnaire on Character Education at Indonesian Language Education Department

\begin{tabular}{|c|c|c|c|c|c|c|c|c|}
\hline \multirow[b]{2}{*}{ Statements } & \multicolumn{2}{|c|}{4} & \multicolumn{2}{|c|}{3} & \multicolumn{2}{|c|}{2} & \multicolumn{2}{|c|}{1} \\
\hline & $\begin{array}{c}\text { Class } \\
\text { I-A }\end{array}$ & $\begin{array}{c}\text { Class } \\
\mathrm{I}-\mathrm{B}\end{array}$ & $\begin{array}{c}\text { Class } \\
\text { I-A }\end{array}$ & $\begin{array}{c}\text { Class } \\
\text { I-B }\end{array}$ & $\begin{array}{c}\text { Class } \\
\text { I-A }\end{array}$ & $\begin{array}{c}\text { Class } \\
\mathrm{I}-\mathrm{B}\end{array}$ & $\begin{array}{c}\text { Class } \\
\text { I-A }\end{array}$ & $\begin{array}{c}\text { Class } \\
\mathrm{I}-\mathrm{B}\end{array}$ \\
\hline Character Education is very beneficial to me & $50 \%$ & $53.1 \%$ & $34.4 \%$ & $37.5 \%$ & $15.5 \%$ & $9.4 \%$ & - & - \\
\hline I always come in the classroom punctually & $45.7 \%$ & $45.7 \%$ & $28.1 \%$ & $31.2 \%$ & $28.1 \%$ & $25 \%$ & - & - \\
\hline I try to say honestly, although it will disadvantage me & $53.1 \%$ & $62.5 \%$ & $9.4 \%$ & $9.4 \%$ & $37.5 \%$ & $28.1 \%$ & - & - \\
\hline $\begin{array}{l}\text { I will try to understand the materials of Basic Culture } \\
\text { Science, although they are difficult }\end{array}$ & $78.1 \%$ & $68.7 \%$ & $15.6 \%$ & $21.9 \%$ & $6.2 \%$ & $9.4 \%$ & - & - \\
\hline $\begin{array}{l}\text { I like to discuss and cooperate with my classmates about the } \\
\text { materials Basic Culture Science }\end{array}$ & $62.5 \%$ & $59.3 \%$ & $15.6 \%$ & $18.7 \%$ & $21.9 \%$ & $21.9 \%$ & - & - \\
\hline $\begin{array}{l}\text { Being different in opinions is a common thing in the } \\
\text { classroom discussion. }\end{array}$ & $59.3 \%$ & $62.5 \%$ & $25 \%$ & $25 \%$ & $15.6 \%$ & $12.5 \%$ & - & - \\
\hline I like to share knowledge with classmates & $59.3 \%$ & $56.2 \%$ & $9.4 \%$ & $9.4 \%$ & $31.2 \%$ & $12.5 \%$ & - & - \\
\hline I always throw rubbish in the proper place & $65.6 \%$ & $65.6 \%$ & $12.5 \%$ & $15.6 \%$ & $21.9 \%$ & $34.4 \%$ & - & - \\
\hline
\end{tabular}

Notes: $\quad$ Strongly Agree (4)

Agree (3)

Disagree (2)

Strongly Disagree (1)

Table 2 shows the result of questionnaire regarding character education as Indonesian Language Education Department. The questionnaire consisted of 7 statements. Statement 1 measured whether or not the character education is beneficial to them. The results demonstrated that $50 \%$ students in class A and $53.1 \%$ in class B strongly agreed. Statement 2 which is related to the character of discipline was indicated by coming in the classroom on time. $45.7 \%$ students in both class A and B strongly agreed on this statement. Statement 3 was about honesty in the students talks. $53.1 \%$ and $62.5 \%$ students in consecutively class A and B strongly agreed that they will say something honestly though it might disadvantage them. In terms of responsibility, the students from class A $(78.1 \%)$ and class B $(68.7 \%)$ were dominantly responsible for trying to understand the materials of Basic Culture Science eventhough they were difficult. 
Statement 4 was intended to investigate the character of responsibility. Next, statement 5 was related to the cooperation with classmates on the materials of Basic Culture Science. $62.5 \%$ students in class A and $59.3 \%$ in class B strongly agreed on the need of cooperation. Meanwhile, statement 6 focused on the caharacters of tolerance and social care. They $(59.3 \%$ class A and $56.2 \%$ class B) liked to share knowledge with classmates. At last, statement 7 was investigating the character of environmental care. $65.6 \%$ students in both classes strongly agreed that they have to throw rubbish in the proper place.

\section{The Results of Observation on the Student Culture \\ Discipline}

Discipline at campus can be identified by the student involvement during the learning process. Discipline is actualized by obedience to campus regulations such as not wearing T-shirt and sandal-shoes. There were still some students breaking the rule by wearing $\mathrm{T}$-shirt and coming late to the morning classroom. In general, they have showed their discipline.

\section{Honesty}

Honesty can also be seen during the learning process in the classroom. Students delivered critics honestly and positively about the way the lecturers teach. They wanted to reveal difficulty in understanding the lecturer's explanation. They spoke facts based on the data they knew during group discussion in the classroom.

\section{Tolerance}

Tolerance at campus existed during the teaching and learning process. Students respect to diversity in terms of opinon, religion, tribe, and skin color among lecturers and friends. They gave opportunities for others to speak and listen. They also said greeting and shake hands to their lecturers.

\section{Cooperation}

Cooperation in the classroom could be seen through group work in doing classroom or take home assignment.

\section{Responsibility}

The duty of students is learning the lesson well, doing the assignment from lecturers, and being discipline in obeying the campus rule.

\section{Social Care}

Social care was shown by the willingness to help others. When one student did not bring a pen, the other lent him. When one student did not understand the material, the other explained it clearly.

\section{Environmental Care}

Keeping the classroom clean before and after the teaching and learning process is a kind of environmental care. Students threw the rubbish in the proper place. They also keep park and plants clean and neat. Besides, they turned off AC, LCD, and 
class lamps after the class was over or before they went home. These indicated that they had the character of environmental care.

\section{The Result of Observation to Lecturer's Culture}

\section{Exemplary}

Exemplary of lecturer is indicated by polite attitude, freshing utterances, fun personality to all students. Lecturers gave examples of discipline, punctual arrival, responsibility, and so on. They came in cheerful faces and gave guidance, assistance, suggestion, and critics sincerely. These physical appearance, personality, and service outside the classroom could give positive image to students.

\section{Discipline}

The disciplinary of lecturers in teaching, their responsibility to duties, love to job contributed to the development of student's character.

\section{Tolerance}

The lecturer spoke in good tones, appreciated their students, and had patient attitude to them were the examples of tolerance.

\section{Cooperation}

There was cooperation between lecturers and students particularly during the teaching and learning process. Cooperation also occurred between lecturers in giving and receiving suggestions and critics, exchanging positive information for the development of learning.

\section{Responsibility}

Responsibility was shown by acquiring effective teaching, becoming the role model for their students, giving advice, acquiring counseling and service techniques, and being able to do evaluation.

\section{Social Care}

Social care could be noticed from the teaching and learning process in the classroom. When the lecturers asked the students about their friends who were absent, they developed relationships to students, listened to them, created warm situation, knew them personally, showed empathy, and met academic and emotional needs of students.

\section{Environmental Care}

Care to environment could be recognized by slow and careful behavior of lecturers in closing the class door. They kept clean the table and classroom during the teaching and learning process. When they saw pieces of paper or plastic in the classroom, they picked them up and threw the rubbish in the dustbin. They also reminded the students to keep clean the environment as this habit is very beneficial for the balance of human creatures in the world.

Character education at Indonesian Language and Literature Education Department, IKIP 
PGRI Bojonegoro, was conducted in three activity groups. First, developing characters by integrating them with the course. Various things related to characters (values, norm, faith and piety, etc.) were designed and implemented in the course namely Basic Culture Course. Introducing the values cognitively, understanding the values affectively, and actualizing the values in the real daily lives of students are the phases that must be carried out. Second, developing characters which are integrated with academic community. Numerous things related to characters (values, norm, spirituality, etc.) must be designed and implemented in the campus management such as management of students, campus regulations, human resources, facilities, financial, library, teaching and learning process, assessment, information, and other management. Third, developing characters by integrating them with extra co-curricular. Some extra cocurricular accommodating character development at this campus are: (1) sports (futsal, shutlecock, etc. ); (2) religion (reading and writing Al Qur'an, hadist review, worship, etc.); (3) arts (dancing, singing, drawing, theatre); (4) KIR (Karya Ilmiah Remaja or Research for Teenagers; (5) Scouts; (6) Latihan Dasar Kepemimpinan Mahasiswa (LDKM) or Basic Exercise of Leadership for students; (7) Volunteer Group of International or Korp Suka Relawan (KSR) PMI; and (8) learning media exhibition and workshop.

\section{The Result of Interviewing the Lecturers}

The researcher conducted interview to threeolecturers by following three questions: 1) Have you made a lesson plan by integrating character education of Samin Community?; 2) Do you have indicators of achievement for character education of Samin Communiy?; Do you have scoring rubric for assessingthis sort of character education? The interview was intended to know the design of integrating, implementing, and evaluating Samin character in the learning activity.

When the lecturers were asked about their preparation before teaching, they said that they had made syllabus and lesson plan integrating character education derived from Samin community in Bojonegoro. They had formulated the lesson plan as the book about Samin was available and the students were asked to read local wisdom of Samin community. The lecturers also mentioned the indicator of character education measurement based on Samin culture. They had assessment rubric and explanation of each descriptor.

\section{The Result of Interviewing the Students}

The interview for students was carried out under the questions as follows: 1) Does your lecturer teach you about character education nased on local wisdom of Samin community?; 2) Does character education motivate you to be better person?; 3) Do lecturers, campus staffs, and other academic officers give you examples of positive characters? Through this interview, the researchers were eager to investigate the implementation of character education derived from Samin community.

The students understood cognitively about character education extracted from Samin culture that had been implanted by the lecturers. Learning character education can 
motivate them to be better. They need examples/models of positive characters from academic community including lecturers and staffs.

\section{The Result of Observation}

The materials of Basic Culture Science have been taught by integrating character education using fairly good strategies and implementation. The students were enthusiastic as the theme of Samin culture they had already known had made the learning becoming easy to understand. After the learning process, most of students became active, creative, and cooperative in group work. Hence, strategies and implementation of teaching character education using local wisdom of Samin community could improve cognitive ability and motivate them to be better.

Initially, disciplinary, honesty, responsibility, cooperation, tolerance, social care, and environmental care at the campus did not run optimally. They did not become the culture that could be seen and reflected in daily lives. After Samin characters were integrated and implemented through some strategies, such as in the learning process, campus management, and extra cocurricular, those 7 characters began to develop and even became a habit. Integrating Samin characters in the learning activity could be done by designing them in the lesson plan, actualizing them learning implementation, and measuring the indicator achievement in learning evaluation.

\section{DISCUSSION}

Higher education integrates character education in every course. Therefore, character education becomes the responsibilities of all lecturers in all courses. These findings are in line with local wisdom-based character education that must be integrated in all courses to get better results (Krull, 2000; Healea, 2006; Mungmachon, 2012). According to Pornpimon et.al (2014); Bachr (2017), implanting character and moral values derived from local wisdom which are considered good and consistent can increase better learning outcomes and attitudes. Sutiyono (2013) also states the same opinion as he said that value education design must not be presented in a specific course instead of in every teaching and learning process in the classroom. The findings of this research was contradictive to the one by Hadi (2015) who revealed that lecturers have not had sufficient skills in integrating values in the teaching and learning process in the classroom yet. The research conducted by Hadi (2015) is not valid to educators in the context of this research.

The teaching of character education integrated in the course of Basic Culture Science was implemented through CTL learning model using thematic approach. It utilized themes to integrate character education derived from Samin book entitled Jamuskalimasada. Some phases taken by lecturers in integrating character education using CTL model and thematic approach were as follows: first, preparation (Komalasari, 2012). This phase involved preparing, mapping Basic Competence, breaking down Competence Standard and Basic Competence in some indicators, determining themes with the context and theme network, identifying and analysing Competence Standard, Basic Competence, indicator as well as formulating syllabus and lesson plan. Second is implementation phase. It was the phase of integrating character values. It involved 
introduction/opening, core activity, and closing. In the core activity, the lecturers integrated character education with the teaching materials or themes derived from Samin culture. Third is assessment phase in which lecturers only did assessment related to character, not touching assessment of character attitude of students, lecturers, campus leader, and employees yet.

This statement means that somebody's kindness must be implanted to be a habit so that good values can be something that usually done every time. Therefore, they must be exercised and accustomed. The students frequently practice kindness values will get accustom to do so both in and out of the campus. In this case, Sutrop et al. (2013) explains that by value education, the students will not only realize values but also live in the values. On the next phase, value habituation of students will become value culture at campus

Character value habituation must be accompanied by role model of value. It became an essential strategy for the head of department and lecturers to grow values to students. These findings have been in line with the previous research done by Ulavere \& Veisson (2015) and Lickona (1991). They have proven that lecturers served vital exemplary in character education. In addition, character education based on local wisdom is essentially needed in the process of growing character values to students. Luther (2001) argues that character education of values is not only focused on touching the introduction of norms and values, but also touching the internalization and real action in daily lives. The success of lecturers in implementing character education to students can be seen from how the students internalize the local wisdom values in their daily behaviour and attitudes (Colgan, 2003).

\section{CONCLUSION}

Value-based vision of study program or campus can be achieved through educational strategy formulation including value habituation, value role model, value internalization, value integration in learning, and cultural value. There were two concepts found in this research; value habituation and value role model which are in line with the concepts found by Mislia \& Darman (2016). Meanwhile, the three concepts as mentioned by Suyatno (2019) i.e. value habituation, value role model, and cultural value strengthened the results of this research. In conclusion, teaching character education to students was related to not only character actualization being programmed in the lesson plan, but also good example provision in the classroom and daily lives. The future researchers may continue the similar study in using local wisdom-based character education for higher education students as it can preserve and socialize the local culture to youths.

\section{ACKNOWLEDGEMENT}

This research project was supported by a grant from the Ministry of Research, Technology, and Higher Education, Indonesia.

\section{REFERENCES}

Anderson, L.W. (1980). Assessing affective characteristic in the schools. Boston: Allyn and Bacon. 
Anggraini, P., \& Tuti K. (2017). Character and local wisdom-based instructional model of Bahasa Indonesia in vocational high schools. J. of Edu. and Practice, 8(5), 23-29.

Arifin, Bafadal, I., Imron, A., \& Sonhadji A. (2017). Cultivating character education through transforming school cultural values. Studia Humanitatis, 37(4), 1-18.

Arikunto, S. 2010. Prosedur penelitian suatu pendekatan praktik. Jakarta: Rineka Cipta.

Atmajawati, Y., \& Hening, W. U. (2018). Learning method, school environment, leadership and its effect on quality education and the excellence student character at muhammadiyah high school. Journal of Education and Practice, 9(26), 118-123.

Bachr, J. (2017). The varieties of character and some implications for character education. Journal of Youth and Adolescence, 46(6), 1153-1161.

Baker, C. et al. (1992) Method slurring: The grounded theory/phenomenology example. Journal of Advanced Nursing, 17(13), 55-60.

Bart, E., Alan, T., Alfred, A., \& Niels, V. (2018). Exemplars and nudges: Combining two strategies for moral education. Journal of Moral Education, 47(3), 346-365.

Brannon, D. (2008). Character education: A joint responsibility. Education Digest, 73(8), 56-60.

Brata, D. P. N., Imron, A., Sonhadji, A., \& Arifin, I. (2017). Headmaster leadership behavior in strengthening character values in vocational high school. Journal of Humanities and Social Sciences, 22(6), 7-12.

Chong, S., \& Cheah, H. M. (2009). A values, skills and knowledge framework for initial teacher preparation programmes. Australian J. of Teacher Education, 34(3), 1-17.

Christen, M. (2018). Comparing cultural differences with domain-specific differences of appreciating and understanding values. Journal of Moral Education, 47(3), 333-345.

Colgan, C. (2003). Making character education work. American School Board Journal, 190(11), 34- 35.

Creswell, J. W. (2013). Educational research: Planning, conducting, and evaluating quantitative and qualitative research. Boston: Pearson Education.

Çubukçu, Z. (2012). İlköğretim öğrencilerinin karakter eğitimi sürecinde örtük programın etkisi. Kuram ve Uygulama Eğitim Bilimleri, 12(2), 1513-1534.

Ereş, F. (2015). Vatandaşlık eğitimi ve karakter eğitimi politikalarının değerlendirilmesine yönelik nitel bir çalışma. Mehmet Akif Ersoy Üniversitesi Ĕgitim Fakültesi Dergisi, 1(36), 120-136.

Greene, M. (1997). The lived world, literature and education. In D. Vandenberg (ed.), Phenomenology \& education discourse (pp. 169-190). Johannesburg: Heinemann.

Guseynov, A. (2017). Pervaya Filosofiya Kak Nravstvennaya Filosofiya [The First Philosophy as The Moral Philosophy] Voprosy Filosofi, 7, 66-74. 
Hadi, R. (2015). The integration of character values in the teaching of economics: A case of selected high schools in Banjarmasin. Int. Education Studies, 8(7), 11-20.

Halim, A., \& Wardana, L. A. (2017). Implementation of the value of mutual cooperation through local wisdom in petik laut district mayangan probolinggo city in social studies. 2nd international conference on educational management and administration. Advances in Economics, Business and Management Res., 45, 127-131.

Healea, C. D. (2006). Character education with resident assistants: A model for developing character on college campuses. The Journal of Education, 186(1), 65-77.

Hidayati, N. A., Herman J. Waluyo, Retno, Winarni, \& Suyitno. (2019). Transformasi Ritual Kebak Jawa Masyarakat Samin Jepang Margomulyo Bojonegoro. Surakarta: Disertasi Pascasarjana UNS.

Holloway, I. (1997). Basic concepts for qualitative research. Oxford: Blackwell.

Inderawati, R. (2012). The development of literary appreciation instrument in building students' character. Sino-US English Teaching, 9(2), 937-945.

Jarrar, Amani. (2013). Moral values education in terms of graduate university students' perspectives: A Jordanian sample. International Education Studies, 6(2), 136-147

Komalasari, K., \& Saripudin, D. (2018). The influence of living values education-based civic education textbook on student's character formation. International Journal of Instruction, 11(1), 395-410. https://doi.org/10.12973/iji.2018.11127a.

Kvale, S. (1996). Interviews: An introduction to qualitative research interviewing. Thousand Oaks, CA: Sage.

Lee, Angela, \& Chi-Ming. (2009). The planning, implementation and evaluation of a character-based school culture project in Taiwan, J of Moral Education, 38(2), 165-184.

Lewis, M., \& Ponzio, V. (2016). Character education as the primary purpose of schooling for the future. Jurnal Ilmiah Peuradeun, 4(2), 137-146.

Lickona, T. (2004). Character matter. New York: Touchstone Rockefeller Center.

Lickona, T. (1991). Educating for character. New York: Bantam Books.

Lincoln, Y. S., \& Guba, E. G. (1985). Naturalistic inquiry. Newbury Park. CA: Sage.

Luther, M. M. (2001). Values and ethics in school education. New Delhi: Tata McGraw-Hill.

Lovat, T. \& Clement, N. (2008). Quality teaching and values education: Coalescing for effective learning. Journal of Moral Education, 37(1), 1-16.

Maypole, J., \& Davies, T. G. (2001). Students" perceptions of constructivist learning in a community college American History II. Community College Review, 29(2), 54-80.

Miles, M. B., \& Huberman, A. M. (1994). Qualitative data analysis: An expanded sourcebook. Thousand Oaks: Sage Publications. 
Mislia, M. A. \& Darman, M. D. (2016). The implementation of character education through scout activities. International Education Studies, 9(6), 130-138.

Mungmachon, M. R. (2012). Knowledge and local wisdom: Community treasure. International Journal of Humanities and Social Science, 2(13), 174-181.

Nguyen, Q. (2016). The Vietnamese values system: A blend of oriental, western and socialist values. International Education Studies, 9(12), 32-40.

Nurdin, E. (2015). The policies on civic education in developing national character in Indonesia. International Education Studies, 8(8) 2015, 207.

Novianti, N. (2017). Teaching character education to college students using bildungsromans. International Journal of Instruction, 10(4), 255-272.

Park, N. (2004). Character strengths and positive youth development. The ANNALS of the American Academy of Political and Social Science, 591(1), 40-54.

Print, M. (2000). Curriculum policy, values and changes in civics education Australia. Asia Pacific Journal of Education, 20(1), 21-35.

Peraturan Presiden Republik Indonesia No. 87 Tahun 2017 tentang Penguatan Pendidikan Karakter.

Pornpimon, C., Wallapha, A., \& Prayuth, C. (2014). Strategy challenges the local wisdom applications sustainability in schools. Procedia-Social and Behavioral Sciences, 112, 626-634. https://doi.org/10.1016/j.sbspro.2014.01.1210.

Rambe, Linda Sari, Deny S., \& Anita Y. (2018). Design of character education model in learning civics at state primary school number. J. of Edu. and Practice, 9(3), 58-65.

S Robinson, D., \& Reed, V. (Eds.). (1998). The A Z of social research jargon. Aldershot, UK: Ashgate.aidek,

Abdul Rahim, Islami R., \& Abdoludin. (2016). Character issues: Reality character problems and solutions through education in Indonesia. Journal of Education and Practice, 7(17), 158-165.

Sankar, Y. (2004). Education in crisis: A value-based model of education provides some guidance. Interchange, 35(7), 127151.

Saripudin, D., \& Komalasari, K. (2016b). Culture-based contextual social studies learning for development of social and cultural values of junior high school students. The Social Sciences, 11(23), 5726-5731. doi: 10.3923/sscience. 2016. 5726.5731.

Savucu, Y., Kanat, M., Karadağ, M., Süreyya. Y., Sezer, \& Ali S. Yücel. (2017). Analysis on the bullying tendencies and value preferences of high school students according to level of receiving physical education and sports course. International Education Studies, 10(7), 40-47.

Senturk, L., \& Aktas, E. (2015). Comparison of Turkish language textbooks for natives in Turkey and in Romania according to value education. $J$ of Val Edu, 13(29), 215-243. 
Silay, N. (2013). Character education at universities. J of Edu Soc Res, 3(1), 43-50.

Sutiyono. (2013). Penerapan Pendidikan Budi Pekerti Sebagai Pembentukan Nilai Siswa Di Sekolah: Sebuah Fenomena Dan Realitas. J. Pend. Karakter, 3(3), 309-320.

Skaggs, G., \& Bodenhorn, N. (2006). relationships between implementing character education, student behavior, and student achievement. J. of Adv. Acad., 8(1), 82-114.

Stallions, M. A., \& Yeats, K. (2003). Enhancing character education for tomorrow's teacher, today: A connected learning partnership model. Florida Association of Teacher Educators Journal, 1(3), 250-260.

Susanti, R. (2013). Penerapan pendidikan karakter di kalangan mahasiswa (The implementation of character education among college students). Jurnal Al-Ta'lim, l(6), 480-487.

Sutrop, M., Harro-Loit, H., \& Jung, N. (2013). Kooli vaartusarenduse Hindamismudel-miks ja kuidas? [Values education assessment model for schools: Why and how?] In M. Sutrop, (Ed.), Vaartuspihine kool. Eesti ja maailma kogemus [Valuesbased school: Experience from Estonia and the world] (pp.199-215). Tartu: U. of Tartu.

Suyatno, Jumintono, Pambudi, D. I., Mardati, A., \& Wantini. (2019). Strategy of values education in the Indonesian education system. Int. J. of Instruction, 12(1), 607-624.

Temiz, N. (2016). Example of character education course design in the light of experienced centred design for higher education. J. of Edu. and Prac., 7(36), 144-155.

Thompson, L. (2010). Character education and school climate (Unpublished master thesis). University of Minnesota Duluth, USA.

Turan, F., \& Ulutas, I. (2016). Using storybooks as a character education tools. Journal of Education and Practice, 7(15), 169-176.

Tim Pendidikan Karakter Ditjen Dikti. (2011). Naskah Akademik Pendidikan Karakter di Perguruan Tinggi. Tim Kemenristekdikti

Tutkun, E., Görgüt, I., \& Erdemir, I. (2017). Physical education teachers' views about character education. International Education Studies, 10(11), 86-99.

Ulavere, P., \& Veisson, M. (2015). Values and values education in estonian preschool child care institutions. Journal of Teacher Education for Sustainability, 17(2), 108-124.

Ülger, M., Yiğittir, S., \& Ercan, O. (2014). Secondary School Teachers' Beliefs on Character Education Competency. Procedia-Social and Behavioral Sci., 131, 442-449.

Yildirim, B. I., \& Dilmac, B. (2015). Investigation of cyber victimization in terms of humanitarian values and socio-demographic variables. J. of Values Edu., 13(1), 7-40.

Yusuf, Y. (2017). Integrasi Pendidikan Karakter Berbasis Qurani dan Kearifan Lokal Bugis. Jurnal Studi Agama dan Masyarakat, 11(2), 247-264. 